\title{
Efektivitas Pemanfaatan Bahan Baku Lokal Sebagai Pakan Ikan Terhadap Peningkatan Produktivitas Budidaya Ikan Lele (Clarias sp.) di Desa Sakatiga, Kecamatan Indralaya, Kabupaten Ogan Ilir, Sumatera Selatan
}

\author{
The Effectiveness of Utilization of Local Raw Materials as Feed to Increase \\ Productivity of Catfish (Clarias sp.) in Sakatiga Village, Indralaya District, \\ Ogan Ilir Regency, South Sumatra
}

\author{
Mohamad Amin ${ }^{1 *}$,Ferdinand Hukama Taqwa ${ }^{1}$, Yulisman $^{1}$, Retno Cahya Mukti ${ }^{1}$, \\ Madyasta Anggana Rarassari ${ }^{1}$ dan Rizki Marli Antika ${ }^{1}$ \\ ${ }^{1}$ Program Studi Budidaya Perairan, Fakultas Pertanian, Universitas Sriwijaya, Indralaya 30662, \\ Indonesia
}

*Correspondence :

amin.unsri@gmail.com

Received : 2020-02-20

Accepted : 2020-08-21

Kata Kunci :

Bahan baku lokal, Bahan pakan, Ikan, Desa Sakatiga

Keywords :

Local raw materials, Feed Ingredients, Fish, Sakatiga Village

\begin{abstract}
Abstrak
Desa Sakatiga terletak di Kecamatan Indralaya Kabupaten Ogan Ilir, Sumatera Selatan, memiliki potensi pengembangan perikanan budidaya. Permasalahan yang sering dialami oleh pembudidaya ikan lele di desa Sakatiga diantaranya tingginya harga pakan dan minimnya pengetahuan masyarakat tentang bahan lokal yang dapat digunakan sebagai bahan baku pakan ikan. Permasalahan tersebut dapat diatasi dengan membuat pakan secara mandiri. Tujuan dari kegiatan ini adalah mengetahui efektivitas pemanfaatan bahan baku lokal sebagai pakan ikan terhadap peningkatan produktivitas budidaya ikan lele (Clarias sp.) di desa Sakatiga, Kecamatan Indralaya, Kabupaten Ogan Ilir, Sumatera Selatan. Metode yang digunakan yaitu dengan penyuluhan dan diskusi, pelatihan pembuatan pakan serta demplot pemanfaatan bahan lokal sebagai bahan baku pakan ikan serta pendampingan teknis oleh tim dan dibantu mahasiswa yang melaksanakan praktik lapang di lokasi mitra. Berdasarkan hasil yang diperoleh menunjukkan adanya peningkatan pengetahuan masyarakat tentang bahan lokal yang dapat digunakan sebagai pakan ikan serta motivasi masyarakat untuk membuat pakan dengan menggunakan bahan baku lokal. Pemanfaatan bahan baku lokal sebagai pakan ikan lele menghasilkan pertumbuhan bobot dan panjang mutlak masing-masing sebesar 9,94 g dan $3,83 \mathrm{~cm}$, laju pertumbuhan harian 2,21\%/hari, efisiensi pakan 103,24\% dan kelangsungan hidup 97\%.
\end{abstract}

\section{Abstract}

Sakatiga Village, located in Indralaya District, Ogan Ilir Regency, South Sumatra, has the potential to develop aquaculture. Problems often experienced by fish farmers in the village of Sakatiga include the high price of feed and the lack 
of public knowledge about local materials that can be used as raw material for fish feed. These problems can be overcome by making feed independently. The purpose of this activity is to evaluate the effectiveness of the utilization of local materials as a raw material for feed to an increase in the productivity of catfish (Clarias sp.) in Sakatiga village, Indralaya District, Ogan Ilir Regency, South Sumatra. The method used is counseling and discussion, training in making food and a demonstration plot using local materials as raw material for fish food and technical assistance by the team and assisted by students who carry out field practices at partner locations. Based on the results obtained indicate an increase in community knowledge about local materials that can be used as fish food and community motivation to make feed using local raw materials. Utilization of local raw materials as catfish feed yields an absolute weight and length growth of $9.94 \mathrm{~g}$ and $3.83 \mathrm{~cm}$ respectively, a daily growth rate of $2.21 \%$ /day, feed efficiency of $103.24 \%$ and survival of $97 \%$.

\section{PENDAHULUAN}

Desa Sakatiga merupakan salah satu desa yang terdapat di Kabupaten Indralaya yang memiliki luas wilayah sebesar \pm 220 Ha (Meilinda, 2016). Sebagian besar wilayah terdiri dari tanah kering dan lahan basah berupa gambut dengan kelembaban yang cukup tinggi. Desa Sakatiga dilalui oleh beberapa sungai yang menjadikan desa ini memiliki potensial untuk dilakukan pengembangan bidang perikanan terutama dibidang budidaya ikan perairan tawar.

Permasalahan yang sering dialami oleh pembudidaya ikan termasuk yang dihadapi oleh kelompok pembudidaya ikan yang menjadi mitra saat ini antara lain kebutuhan pakan ikan yang ekonomis untuk mendukung pertumbuhan dan produksi ikan yang dipelihara menjadi meningkat, tingginya harga pakan komersial, minimnya pengetahuan pembudidaya ikan mengenai bahan alternatif yang dapat dijadikan pakan, teknis pembuatan pakan serta manajemen pemberian pakan ikan. Sebagian besar pembudidaya ikan masih mengandalkan suplai pakan dari pabrikan (pakan komersial), sementara harga pakan hingga saat ini masih tergolong tinggi. Hal ini menyebabkan ketidakseimbangan pendapatan yang diperoleh pembudidaya ikan dengan biaya produksi yang dikeluarkan selama proses produksi, mengingat lebih dari $60 \%$ dari total biaya produksi bersumber dari biaya pakan. (Sari et al., 2017).

Solusi untuk mengatasi beberapa permasalahan pembudidaya antara lain dengan melakukan sosialisasi atau penyuluhan tentang bahan alternatif yang dapat dijadikan sebagai bahan pakan ikan, syarat bahan alternatif serta cara pengolahannya. Beberapa syarat bahan alternatif pakan diantaranya mudah didapat, harga murah dan memiliki kandungan nutrisi yang cukup tinggi (Suprayudi et al., 2011). Selain itu, untuk mengatasi ketergantungan pembudidaya terhadap pakan komersial yang harganya tinggi dapat dilakukan dengan pembuatan pakan mandiri berbahan baku lokal.

Bahan baku lokal yang dapat digunakan antara lain tepung ikan, tepung bungkil kedelai, ampas tahu dan dedak. Palinggi et al. (2002) melaporkan bahwa tepung ikan memiliki kandungan protein sebesar $65,6 \%$, lemak 4,8\%, BETN sebesar $14,2 \%$, serat kasar 2,8\%, dan kadar abu 12,6\%. Puastuti et al. (2014) melaporkan bahwa tepung bungkil kedelai mengandung protein kasar (PK) 13,98\%, serat kasar (SK) 24\%, lemak kasar (LK) $9,5 \%$, abu 4,3\%, BETN 35,0\%, Ca 0,22\%, air 10,4\%. Melati et al. (2010) 
melaporkan bahwa kandungan ampas tahu antara lain protein 21,23-26,60\%, karbohidrat 19,00 - 41,3\%, lemak 16,22 $18,3 \%$, serat kasar $29,59 \%$, kadar abu $5,45 \%$, air 9,84\%. Selanjutnya Suhenda et al. (2010) melaporkan bahwa dedak padi mengandung protein $12,9 \%$; lemak $13 \%$; dan serat kasar $11,4 \%$.

Pembuatan pakan mandiri berbahan lokal dengan perhitungan formulasi pakan sesuai kebutuhan nutrisi ikan. Nutrisi tersebut harus sesuai dengan kebutuhan ikan sehingga dapat meningkatkan efisiensi pakan dan pertumbuhan ikan. (Hidayat et al., 2013). Sebaliknya, apabila pakan yang diberikan tidak sesuai dengan kebutuhan nutrisi ikan maka akan mengakibatkan tingginya efisiensi pakan dan rendahnya pertumbuhan ikan. Penggunaan bahan baku lokal ini sudah banyak digunakan sebagai pakan antara lain pada ikan nila (Lestari et al., 2013), ikan patin (Nahak, 2016), ikan bandeng (Usman et al., 2014), dan ikan mas (Suhenda et al., 2010).

Melalui kegiatan ini diharapkan dapat mentransfer ilmu dan teknologi diari pihak akademisi kepada masyarakat terutama pembudidaya ikan sebagai khalayak sasaran. Pembuatan pakan dengan memanfaatkan bahan baku lokal juga diharapkan dapat mengurangi penggunaan pakan komersial sehingga dapat menekan biaya produksi terutama berasal dari biaya pakan, dan produksi ikan yang dipelihara dapat meningkat dengan pertumbuhan ikan yang tinggi.

\section{METODOLOGI}

\section{Waktu dan Tempat}

Kegiatan ini dilaksanakan pada bulan Oktober-Desember 2019 di kelompok mitra Samak Berkah di Desa Sakatiga, Kecamatan Indralaya, Kabupaten Ogan Ilir, Sumatera Selatan.

\section{Materi Penelitian}

Alat-alat yang digunakan dalam penelitian ini adalah mesin pencetak pakan, $\mathrm{pH}$ meter (ketelitian 0,1 unit $\mathrm{pH}$ ), termometer (ketelitian $0,1^{\circ} \mathrm{C}$ ), timbangan (ketelitian 0,1 g), dan waring ukuran $2 \mathrm{x}$ $1 \mathrm{x} 1 \mathrm{~m}$ untuk wadah pemeliharaan ikan. Bahan-bahan yang digunakan meliputi ikan lele ukuran 10-11 cm, tepung ikan (protein 50-55\%), tepung bungkil kedelai (protein 40-45\%), ampas tahu (protein 25-27\%), dedak (BETN 69,34\%), minyak nabati, premix, tapioka, dan air sebagai media pemeliharaan.

\section{Rancangan Penelitian}

Penelitian ini menggunakan metode eksperimen tunggal yaitu penggunaan pakan berbahan lokal sebagai pakan ikan lele dengan dua ulangan. Parameter yang diamati antara lain pertumbuhan bobot dan panjang mutlak, efisiensi pakan, laju pertumbuhan harian, kelangsungan hidup serta parameter kualitas air berupa suhu dan $\mathrm{pH}$.

\section{Prosedur Kerja}

Pelaksanaan kegiatan meliputi: 1) Persiapan yaitu dengan survei langsung ke lokasi mitra serta penelusuran minat dan pengetahuan pembudidaya ikan mengenai pakan ikan. Pada tahap ini dilakukan koordinasi tim pelaksana kegiatan pengabdian dan kelompok pembudidaya serta perangkat desa, persiapan alat dan bahan. 2) Tahap penyuluhan yaitu melalui penyampaian materi, diskusi serta praktik langsung membuat pakan ikan berbahan lokal menggunakan alat peraga di lokasi mitra. Pada tahap ini juga dilakukan penyebaran kuesioner sebelum dan sesudah kegiatan yang bertujuan untuk mengetahui pemahaman masyarakat tentang materi yang diberikan. 3) Tahap monitoring dan evaluasi yaitu dengan pendampingan teknis budidaya ikan demplot oleh tim dan dibantu mahasiswa yang melaksanakan praktik lapang di lokasi mitra.

\section{Pembuatan Pakan}

Pakan yang digunakan berasal dari campuran beberapa bahan baku diantaranya tepung ikan, ampas tahu, tepung kedelai, dedak, tapioka, minyak ikan dan vitamin mix. Komposisi bahan 
pakan yang digunakan disajikan pada

Tabel 1.

Tabel 1. Formulasi pakan yang digunakan.

\begin{tabular}{lc}
\hline \multicolumn{1}{c}{ Bahan Pakan } & Persentase Komposisi (\%) \\
\hline Tepung Ikan & 17,8 \\
Tepung Ampas Tahu & 17,8 \\
Tepung Kedelai & 17,8 \\
Dedak & 22,3 \\
Tapioka & 22,3 \\
Minyak Ikan & 1 \\
Premix & 1 \\
Jumlah & 100 \\
\hline Protein (\%) & 25 \\
Lemak (\%) & 8 \\
BETN* (\%) & 49 \\
Serat kasar (\%) & 34 \\
Abu (\%) & 12 \\
GE** (kkal/kg) & 4280 \\
\hline
\end{tabular}

Keterangan: *Bahan Ekstrak Tanpa Nitrogen, ${ }^{* *} \mathrm{GE}$ (gross energy): protein 5,6 kkal/g, lemak 9,4 $\mathrm{kkal} / \mathrm{g}, \mathrm{BETN}=4,1 \mathrm{kkal} / \mathrm{g}$ (NRC, 1993).

Pembuatan pakan dilakukan dengan menimbang bahan pakan sesuai dengan formulasi yang telah ditentukan. Selanjutnya dilakukan pencampuran bahan pakan dimulai dengan mencampur bahan yang jumlahnya paling sedikit terlebih dahulu yaitu minyak nabati dan premix (vitamin dan mineral mix), diikuti dedak halus, ampas tahu, dan tepung ikan sampai homogen. Kemudian tambahkan air sebanyak $40 \%$ dan aduk hingga bercampur. Setelah campuran bahan menjadi homogen dilakukan pencetakan pakan menggunakan mesin pencetak pakan. Pakan hasil cetakan kemudian dikeringkan dengan cara dijemur di bawah sinar matahari. Setelah kering, pakan disimpan dalam wadah tertutup dan diletakkan di ruangan yang kering (tidak lembab dan tidak terkena cahaya matahari langsung).

\section{Pemeliharaan Ikan}

Pemeliharaan ikan dilakukan dalam waring berukuran $2 \times 1 \times 1 \mathrm{~m}$ dengan padat tebar sebanyak 100 ekor/waring. Sebelum ditebar ikan diaklimatisasi terlebih dahulu dan diadaptasikan dengan pakan selama 7 hari. Kemudian ikan dipuasakan selama 24 jam lalu ditimbang bobot dan panjangnya. Ikan diberikan pakan sebanyak 3 kali sehari yaitu pukul 08.00, 12.00 dan 17.00 WIB sebanyak 3\% dari biomassa ikan. Pemeliharaan ikan dilakukan selama 30 hari. Pengukuran suhu dan $\mathrm{pH}$ dilakukan setiap pagi hari. Jika ada ikan mati, ikan diukur bobot dan panjangnya.

\section{Analisis Data}

Pertumbuhan bobot mutlak dihitung menggunakan rumus berdasarkan Zonneveld et al. (1991):

$\mathrm{W}=\mathrm{Wt}-\mathrm{Wo}$

Keterangan:

$\mathrm{W}=$ pertumbuhan rata-rata bobot ikan yang dipelihara $(\mathrm{g})$

$\mathrm{Wt}=$ bobot rata-rata ikan pada akhir pemeliharaan $(\mathrm{g})$

Wo $=$ bobot rata-rata ikan pada awal pemeliharaan $(\mathrm{g})$

Pertumbuhan panjang mutlak dihitung menggunakan rumus berdasarkan Zonneveld et al. (1991):

$\mathrm{L}=\mathrm{Lt}-\mathrm{Lo}$

Keterangan:

$\mathrm{L}=$ pertumbuhan panjang mutlak $(\mathrm{cm})$

Lt $=$ panjang rata-rata ikan akhir $(\mathrm{cm})$

Lo $=$ panjang rata-rata ikan awal $(\mathrm{cm})$

Laju pertumbuhan harian dihitung menggunakan rumus berdasarkan Zonneveld et al. (1991): 
$\mathrm{LPH}=\frac{\ln \mathrm{Wt}-\ln \mathrm{Wo}}{\mathrm{t}} \times 100$

Keterangan:

$\mathrm{LPH}=$ laju pertumbuhan harian (\%/hari)

$\mathrm{Wt}=$ bobot rata-rata ikan pada akhir pemeliharaan $(\mathrm{g})$

$\mathrm{Wo}=$ bobot rata-rata ikan pada awal pemeliharaan $(\mathrm{g})$

$\mathrm{t} \quad=$ lama pemeliharaan (hari)

Efisiensi pakan dihitung

menggunakan rumus Effendi (1997):

$\mathrm{EP}=\frac{(\mathrm{Bt}+\mathrm{Bd})-\mathrm{Bo}}{\mathrm{F}} \times 100 \%$

Keterangan:

$\mathrm{EP}=$ efisiensi pakan (\%)

$\mathrm{Bt}=$ biomassa ikan akhir $(\mathrm{g})$

$\mathrm{Bd}=$ biomassa ikan mati $(\mathrm{g})$

Bo = biomassa ikan awal (g)

$\mathrm{F} \quad=$ jumlah pakan yang dikonsumsi (g)

Persentase kelangsungan hidup dihitung menggunakan rumus Effendi (1997):

$\mathrm{KH}=\frac{\mathrm{Nt}}{\mathrm{No}} \times 100 \%$

Keterangan:

$\mathrm{KH}=$ kelangsungan hidup ikan (\%)

$\mathrm{Nt}=$ jumlah ikan akhir (ekor)

No. = jumlah ikan awal (ekor)

\section{HASIL DAN PEMBAHASAN}

Kegiatan pengabdian kepada masyarakat dikatakan berhasil apabila masyarakat dapat memahami atas materi yang diberikan dan masyarakat dapat mengaplikasikannya dalam kegiatan budidaya, oleh karena itu dipilih tahapan kegiatan berupa penyuluhan, monitoring dan evaluasi. Hal ini dilakukan sesuai dengan yang dilakukan oleh Yunaidi et al. (2019) yang melakukan kegiatan pengabdian kepada masyarakat tentang aplikasi pakan pelet buatan untuk peningkatan produksi budidaya ikan air tawar. Kegiatan penyuluhan dilakukan dengan memberikan materi tentang pemanfaatan bahan lokal sebagai pakan ikan lele kemudian dilanjutkan dengan diskusi dan praktik pembuatan pakan ikan berbahan baku lokal. Tujuan dari kegiatan penyuluhan agar masyarakat dapat mengetahui serta membuat pakan ikan lele menggunakan bahan baku lokal.

Setelah kegiatan penyuluhan, dilanjutkan dengan kegiatan monitoring. Kegiatan monitoring ini dilakukan dengan tujuan melihat tingkat pemahaman masyarakat dalam mengaplikasikan materi dan pakan yang sudah dibuat untuk ikan lele yang dibudidayakan. Pada kegiatan monitoring ini, dilakukan pendampingan teknis pada budidaya ikan lele menggunakan bahan baku lokal yang sudah dibuat di lokasi mitra. Tahap terakhir yaitu evaluasi. Evaluasi bertujuan untuk melihat hasil penerapan iptek berupa pakan berbahan baku lokal yang telah diberikan terhadap pertumbuhan, efisiensi pakan serta kelangsungan hidup ikan lele yang dibudidayakan.

Kegiatan penyuluhan dilakukan dengan melibatkan seluruh tim, pembudidaya ikan dan mahasiswa yang terlibat dalam praktik lapang di lokasi pengabdian. Dokumentasi kegiatan penyuluhan disajikan pada Gambar 1.
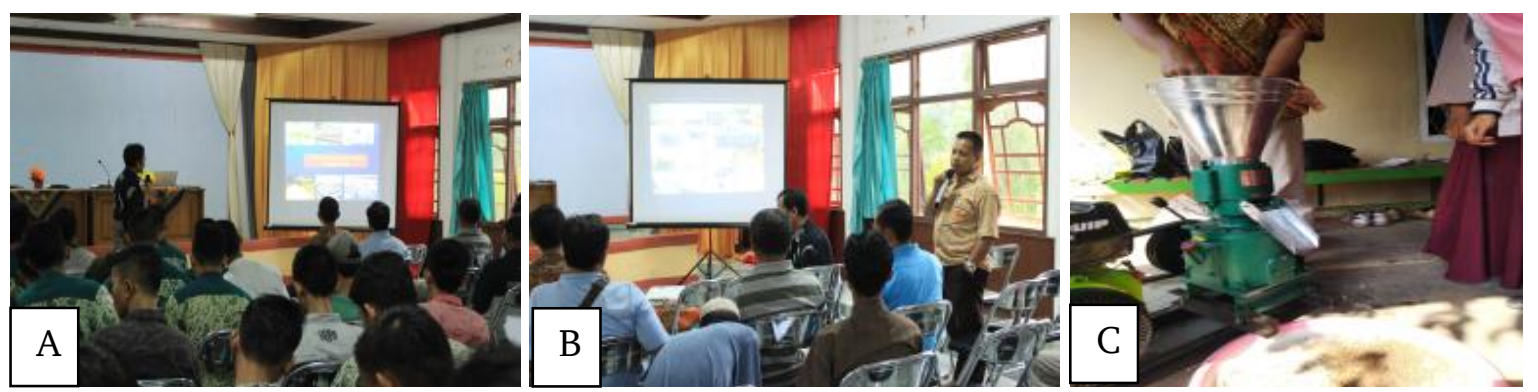

Gambar 1. Kegiatan penyuluhan: A) Penyampaian materi, B) Diskusi, C) Praktik pembuatan pakan ikan.

Setelah pemaparan materi, dilakukan diskusi dengan kelompok pembudidaya ikan. Para pembudidaya menunjukkan antusiasnya dalam merespons materi yang disampaikan. Hal ini terlihat dengan adanya beberapa 
pertanyaan yang disampaikan antara lain 1) alternatif bahan pakan lain, 2) manajemen pemberian pakan, 3) cara mengatasi ikan yang tidak mau makan. Berdasarkan hasil kuesioner pada awal kegiatan menunjukkan bahwa sebagian besar pembudidaya belum pernah mengikuti pelatihan/penyuluhan tentang pembuatan pakan tambahan. Padahal di sisi lain, sebagian besar masyarakat mengalami kendala/permasalahan terkait biaya pakan.

Beberapa permasalahan diantaranya harga pakan komersial yang tinggi tidak sebanding dengan harga jual ikan sehingga keuntungan yang diperoleh juga sedikit. Harapan pembudidaya, untuk diberi penyuluhan secara bantuan secara

Apakah Bapak/Ibu pernah mengikuti pelatihan tentang pembuatan pakan ikan?

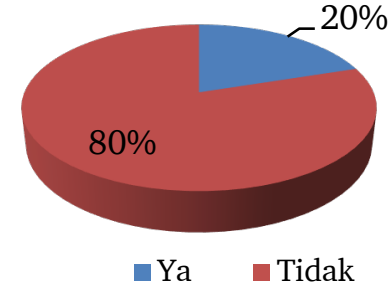

teknis untuk dapat membuat pakan sendiri sehingga penggunaan pakan komersial dapat dikurangi sehingga biaya pakan semakin rendah dan keuntungan semakin tinggi. Sebagian besar (90\%) pembudidaya/masyarakat Desa Sakatiga belum pernah membuat pakan sendiri atau mengikuti pelatihan pembuatan pakan ikan (Gambar 2a). Pada akhir kegiatan dilakukan pengisian kuesioner kembali, kelompok pembudidaya umumnya menganggap bahwa materi pelatihan pembuatan pakan tambahan yang diberikan sangat bermanfaat dan menambah pengetahuan serta memotivasi masyarakat untuk membuat pakan tambahan sendiri pada ikan budidaya (Gambar 2b).

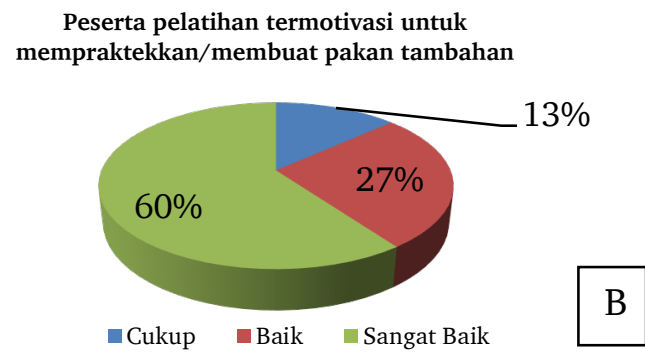

Gambar 2. Hasil kuesioner penyuluhan: A) sebelum, B) sesudah.

Kegiatan monitoring berupa pendampingan teknis budidaya ikan lele yang diberikan pakan berbahan lokal di lokasi mitra selama 30 hari. Ikan yang dipelihara diberikan pakan sebanyak 5\% dari biomassa ikan. Data hasil pemeliharaan ikan lele disajikan pada Tabel 2.

Tabel 2. Pertumbuhan bobot mutlak, pertumbuhan panjang mutlak, laju pertumbuhan harian, efisiensi pakan, kelangsungan hidup ikan lele.

\begin{tabular}{lc}
\hline Parameter & Hasil \\
\hline Pertumbuhan bobot mutlak $(\mathrm{g})$ & $9,94 \pm 1,09$ \\
Pertumbuhan panjang mutlak $(\mathrm{cm})$ & $3,83 \pm 0,38$ \\
Laju pertumbuhan harian (\%) & $2,21 \%$ \\
Efisiensi pakan (\%) & $103,24 \pm 8,97$ \\
SR (\%) & $97,00 \pm 0,00$ \\
\hline
\end{tabular}

Berdasarkan data pada Tabel 2 terlihat bahwa pemberian pakan berbahan baku lokal mampu meningkatkan pertumbuhan ikan lele. Hal tersebut membuktikan bahwa pakan yang digunakan memiliki kandungan nutrisi yang sesuai dengan kebutuhan nutrisi ikan lele. Sebagaimana dinyatakan oleh Utomo et al. (2013) bahwa pertumbuhan terjadi apabila pakan yang diberikan memiliki kandungan nutrisi yang baik dan jumlah yang sesuai dengan kebutuhan ikan. Pertumbuhan terjadi apabila terdapat kelebihan energi setelah digunakan untuk maintenance ikan. 
Kandungan energi pakan yang digunakan sebesar $4280 \mathrm{kkal} / \mathrm{kg}$. Nilai ini masih dalam toleransi kebutuhan energi pakan ikan lele. Zonneveld et al. (1991) menyatakan bahwa ikan lele dapat tumbuh baik pada kandungan energi pakan sebesar $4000-5000 \mathrm{kkal} / \mathrm{kg}$. Tingginya kandungan energi pakan berasal dari kandungan karbohidrat, lemak dan protein. Pakan yang digunakan memiliki kandungan protein sebesar 25\%, lemak 8\%, BETN 49\%, serat kasar 34\% dan kadar abu 12\%. Halver dan Hardy (2002) menyatakan bahwa ikan Channel catfish dapat tumbuh maksimal dengan kadar protein pakan sebesar $24-26 \%$. Nilai ini lebih rendah dibandingkan dengan penelitian Albarman (2015) yang menyatakan bahwa kinerja pertumbuhan ikan lele yang terbaik diperoleh pada kandungan protein pakan sebesar 27\% dan 29\%. Kebutuhan lemak untuk ikan catfish berkisar 4-18\% (NRC, 1993).

Kandungan karbohidrat dalam pakan terdiri dari BETN dan serat kasar. Ikan lele merupakan jenis ikan karnivora yang dapat memanfaatkan karbohidrat pada kadar 10-20\% (Watanabe, 1988). Tingginya nilai BETN dan serat kasar pada pakan yang digunakan yaitu sebesar 49\% dan $34 \%$ berasal dari tingginya penggunaan bahan nabati yaitu tepung bungkil kedelai, dedak dan ampas tahu. Tepung bungkil kedelai selain digunakan sebagai sumber protein karena memiliki kandungan protein yang tinggi, juga memiliki kandungan karbohidrat yang tinggi. Kandungan BETN dan serat kasar pada tepung kedelai sebesar 35,0\% dan 24\% (Puastuti et al., 2014).

Suhenda et al. (2010) melaporkan bahwa dedak padi memiliki karbohidrat cukup tinggi yaitu BETN 49,42\% dan serat kasar 3,64\%. Kandungan BETN dan serat kasar ampas tahu menurut Islamiyati et al. (2010) sebesar 38,06\% dan 25,43\%. Tingginya kandungan serat kasar menyebabkan rendahnya penyerapan zat makanan dalam saluran pencernaan sehingga menghasilkan pertumbuhan ikan yang rendah. Serat kasar merupakan komponen karbohidrat kompleks yang dapat memberikan rasa kenyang. Semakin tinggi kandungan serat kasar pada pakan maka ikan akan mudah kenyang. Hal ini menyebabkan rendahnya jumlah konsumsi pakan ikan yang berakibat pada rendahnya pertumbuhan ikan. (Piliang 2006). Mokoginta et al. (2003) menambahkan bahwa semakin tinggi serat kasar maka semakin rendah kecernaan pakan sehingga pertumbuhan ikan yang dihasilkan rendah.

Pertumbuhan bobot mutlak yang dihasilkan sebesar 9,94 g dan pertumbuhan panjang mutlak sebesar $3,83 \mathrm{~cm}$. Nilai pertumbuhan yang dihasilkan termasuk tinggi. Defrizal dan Khalil (2015) melaporkan bahwa ikan lele yang diberi pakan dengan formulasi berupa tepung ikan dan dedak menghasilkan pertumbuhan tertinggi yaitu rata-rata pertambahan bobot sebesar 7,48 g, rata-rata pertambahan panjang sebesar $6,03 \mathrm{~cm}$. Pertumbuhan ikan dipengaruhi oleh faktor internal dan eksternal. Menurut Arisa et.al. (2018), pertumbuhan ikan sangat bergantung pada energi yang tersedia dalam pakan. Laju pertumbuhan berbanding lurus dengan laju pertumbuhan harian. Laju pertumbuhan harian yang dihasilkan sebesar 2,21\%/hari. Nilai laju pertumbuhan harian ini lebih tinggi jika dibandingkan dengan penelitian Abidin et al. (2015) bahwa laju pertumbuhan harian ikan lele terbaik diperoleh dari pakan berbahan lokal dengan komposisi formulasi tepung ikan; jagung; dedak dengan komposisi berbeda sebesar $1,4 \%$ /hari dan $1,2 \%$ /hari.

Efisiensi pakan merupakan persentase pemanfaatan pakan untuk menghasilkan pertumbuhan ikan. Semakin tinggi nilai efisiensi pakan menunjukkan bahwa semakin efisien pakan tersebut dimanfaatkan oleh ikan untuk pertumbuhan. Hal ini ditunjukkan dengan nilai pertumbuhan ikan lele yang juga tinggi. Nilai efisiensi pakan yang diperoleh pada kegiatan ini sebesar $103,24 \%$. Nilai efisiensi pakan yang lebih dari $100 \%$ diduga adanya pakan alami yang ada di media budidaya sehingga 
mampu dimanfaatkan oleh ikan lele. Hal ini sesuai dengan penelitian Haris (2013) yang melaporkan bahwa nilai efisiensi pakan ikan lele ukuran $5 \mathrm{~cm}$ sebesar $119,37 \%$ dan Mukti et al. (2020) yang melaporkan bahwa penggunaan pakan tambahan berupa dedak yang difermentasi dengan ampas tahu menghasilkan nilai efisiensi pakan ikan patin sebesar $133,0 \%$.

Tingginya nilai efisiensi pakan menunjukkan bahwa pakan yang diberikan memiliki kualitas yang baik. Semakin baik kualitas suatu pakan maka semakin tinggi nilai efisiensi pakan yang dihasilkan. Kualitas pakan ikan ditentukan oleh sumber dan komposisi bahan, daya cerna bahan, serta jumlah dan seimbangnya berbagai asam amino. Semakin tinggi nilai kecernaan pakan maka semakin efisien pakan. Hal ini sesuai dengan pernyataan Gunadi et al. (2010) bahwa kecernaan pakan merupakan salah satu indikator yang menentukan nilai efisiensi pakan.

Nilai kelangsungan hidup yang dihasilkan sebesar 97\%. Tingginya nilai kelangsungan hidup menunjukkan bahwa pakan yang diberikan mencukupi kebutuhan ikan. Selain itu, kelangsungan hidup juga dipengaruhi oleh kualitas air pada media budidaya. Nilai kualitas air berupa suhu dan $\mathrm{pH}$ masing-masing sebesar 27,3-30 ${ }^{\circ} \mathrm{C}$ dan 6,25-6,66. Nilai suhu dan $\mathrm{pH}$ yang dihasilkan masih dalam kisaran optimum ikan lele. Hal ini sesuai dengan SNI (2014) bahwa kisaran suhu optimal untuk pembesaran ikan lele sebesar $25-30{ }^{\circ} \mathrm{C}$ sedangkan kisaran nilai $\mathrm{pH}$ optimum ikan lele sebesar 6-8,5 (Hermawan et al., 2012).

\section{KESIMPULAN}

Berdasarkan hasil yang diperoleh menunjukkan adanya peningkatan pengetahuan masyarakat tentang bahan lokal yang dapat digunakan sebagai pakan ikan serta motivasi masyarakat untuk membuat pakan dengan memanfaatkan bahan baku lokal. Pemanfaatan bahan baku lokal sebagai pakan ikan lele menghasilkan pertumbuhan bobot dan panjang mutlak sebesar 9,94 g dan 3,83 $\mathrm{cm}$, efisiensi pakan sebesar $103,24 \%$ dan kelangsungan hidup sebesar $97 \%$.

\section{UCAPAN TERIMA KASIH}

Ucapan terima kasih kami sampaikan kepada Lembaga Penelitian dan Pengabdian kepada Masyarakat (LPPM) Universitas Sriwijaya atas pendanaan kegiatan PKM tahun anggaran 2019. Terima kasih juga kami sampaikan kepada Kelompok pembudidaya Samak Berkah Desa Sakatiga serta seluruh pihak yang telah berpartisipasi dan bekerja sama dalam pelaksanaan kegiatan pengabdian ini.

\section{DAFTAR PUSTAKA}

Abidin Z., Junaidi M., Paryono, Cokrowati, N. dan Yuniarti S., 2015. Pertumbuhan dan konsumsi pakan ikan lele (Clarias sp.) yang diberi pakan berbahan baku lokal. DEPIK Jurnal Ilmu - Ilmu Perairan, Pesisir dan Perikanan, 4(1), pp. 33-39. https://doi.org/10.13170/depik.1.1 .2360

Albarman A., 2015. Kinerja pertumbuhan ikan lele Clarias sp. yang diberi pakan dengan kualitas berbeda. Skripsi. Institut Pertanian Bogor.

Arisa, I.I., Fadli, N., Anwar, A., Nizamudin, N. dan Parmakope, P., 2018. Utilization of organic waste as material of fish feed production for African catfish (Clarias gariepinus). IOP Confrence Series Earth and Environmental Science, 216(1): 0120 35. https://doi.org/10.1088/17551315/216/1/012035

Defrizal dan Khalil, M., 2015. Pengaruh formulasi yang berbeda pada pakan pelet terhadap pertum-buhan ikan lele dumbo (Clarias gariepinus). Acta Aquatica, 2(2), pp. 101-106. https://doi.org/10.29103/aa.v2i2.3 42

Effendi, M.I., 1997. Biologi Perikanan. Yayasan Pustaka Nusantara. Yogyakarta. 
Gunadi B., Febrianti R. dan Lamanto, 2010. Keragaan kecernaan pakan tenggelam dan terapung untuk ikan lele dumbo (Clarias gariepinus) dengan dan tanpa aerasi. Prosiding Forum Inovasi Teknologi Akuakultur. 7 p. https://adoc.tips/keragaankecernaan-pakan-tenggelam-danterapung-untuk-ikan-l.html

Halver J.E. dan Hardy R.W., 2002. Fish nutrition. Third Edition. Academic Press Inc. California. pp. 712-713.

Haris, A.S., 2013. Evaluasi kinerja pendederan ikan lele Clarias sp. ukuran $5 \mathrm{~cm}$ di dalam sistem resirkulasi pada padat penebaran dan sumber benih yang berbeda. Skripsi. Institut Pertanian Bogor.

Hermawan A., Iskandar T. dan Ujung, S., 2012. Pengaruh padat tebar terhadap kelangsungan hidup pertumbuhan lele dumbo (Clarias gariepinus Burch) di Kolam Kali Menir Indramayu. Jurnal perikanan dan kelautan. 3(3), pp. 85-93. http: //jurnal.unpad.ac.id/jpk/article/do wnload/1413/1407

Hidayat, D., Sasanti, A.D. dan Yulisman, 2013. Kelangsungan hidup, pertumbuhan dan efisiensi pakan ikan gabus (channa striata) yang diberi pakan berbahan baku tepung keong mas (pomacea sp). Jurnal Akuakultur Rawa Indonesia, 1(2), pp.161-172. https://doi.org/10.367 06/jari.v1i2.1736

Islamiyati R., Jamila dan Hidayat, A.R., 2010. Nilai nutrisi ampas tahu yang difermentasi dengan berbagai level ragi tempe. Seminar Nasional Teknologi Peternakan dan Veteriner, pp. 815-818.

Lestari, S.F., Yuniarti, S. dan Abidin, Z., 2013. Pengaruh formulasi pakan berbahan baku tepung ikan, tepung jagung, dedak halus dan ampas tahu terhadap pertumbuhan Ikan Nila (Oreochromis sp). Jurnal Kelautan: Indonesian Journal of Marine Science and Technology, 6(1), pp.36-46. https://doi.org/10.21107/jk.v6i1.8 31
Meilinda, A.A., 2016. Tinjauan fiqh jinayah terhadap perlindungan korban tindak pidana kekerasan dalam rumah tangga (studi kasus di Desa Sakatiga Kecamatan Indralaya Kabupaten Ogan Ilir. Skripsi. Universitas Islam Raden Fatah.

Melati, I., Azwar, Z.I. dan Kurniasih, T., 2010, April. Pemanfaatan ampas tahu terfermentasi sebagai substitusi tepung kedelai dalam formulasi pakan ikan patin. In Prosiding Forum Inovasi Teknologi Akakukultur (pp. 713-719).

Mokoginta, I., Utomo, N.P., Akbar, A.D. dan Setiawati, M., 2003. Penggunaan tepung singkong sebagai subtitusi tepung terigu pada pakan ikan mas (Cyprinus carpio L). Jurnal Akuakultur Indonesia, 2(2), pp. 79-83. https://doi.org/10.1902 7/jai.2.79-83

Mukti, R.C., Amin, M., Wijayanti, M., Yulisman, Octaviani, R. dan Pangawikan, A.D., 2020. Pemeliharaan ikan patin (Pangasius sp.) dengan pemberian pakan tambahan, di Desa Pulau Semambu, Kecamatan Indralaya Utara, Kabupaten Ogan Ilir. Logista: Jurnal Ilmiah Pengabdian kepada Masyarakat, 4(1), pp. 25-31. https: //doi.org/10.25077/logista.4.1.2531.2020

Nahak, D.L., 2016. Pengaruh perbedaan komposisi pakan ampas tahu terfermentasi Rhizopus oryzae terhadap pertumbuhan berat ikan patin (Pangasius djambal) pada skala laboratorium. Skripsi. Univesitas Sanata Dharma Yogyakarta.

NRC (National Research Council), 1993. Nutrient Requirement of Warm Water Fishes and Shelfish. Nutritional Academy of Sciences, Washington D. C. $102 \mathrm{p}$.

Palinggi, N.N., Rachmansyah dan Asda, L., 2002. Potensi bahan baku pakan lokal di Sulawesi Selatan. AustraliaIndonesia Fisheries Showcase. 20 
Years of Collaborative Research. Jakarta.

Piliang, 2006. Fisiologi Nutrisi. Vol. ke-2. IPB Press. Bogor.

Puastuti, W., Yulistiani, D. dan Susana, I.W.R., 2014. Evaluasi nilai nutrisi bungkil inti sawit yang difermentasi dengan kapang sebagai sumber protein ruminansia. JITV, 19(2), pp.143-151. http://dx.doi.org/10. 14334/jitv.v19i2.1043

Sari, I.P., Yulisman dan Muslim, 2017. Laju pertumbuhan dan efisiensi pakan ikan nila (Oreochromis niloticus) yang dipelihara dalam kolam terpal yang dipuasakan secara periodik. Jurnal Akuakultur Rawa Indonesia, 5(1), pp. 45-55. https://doi.org/10.36706/jari.v5i1. 5807

SNI [Standar Nasional Indonesia], 2014. Ikan Lele Dumbo (Clarias sp). Badan Standardisasi Nasional. Jakarta. SNI 6484.3

Suhenda, N., Samsudin, R. dan Melati, I., 2010. Peningkatan Kualitas Bahan Nabati (Dedak Padi dan Dedak Polar) Melalui Proses Fermentasi (Rhizopus oligosporus) dan Penggunaannya dalam Ikan Mas (Cyprinus carpio). In Prosiding Forum Inovasi Teknologi Akuakultur (Vol. 689, p. 695).

Suprayudi, M.A., Dimahesa, W., Jusadi, D., Setiawati, M. dan Ekasari, J., 2011. Efek suplementasi crude enzim cairan rumen domba pada pakan berbasis sumber protein nabati terhadap pertumbuhan ikan nila Oreochromis niloticus. Jurnal Iktiologi Indonesia, 11(2), pp. 177183. https://dx.doi.org/10.32491/ jii.v11i2.141

Usman, Kamaruddin, Palinggi, N.N. dan Laining, A., 2014. Aplikasi pakan berbasis bahan baku lokal dan hasil samping dalam pakan pembesaran ikan bandeng di lahan pembudidaya. Prosiding Forum Inovasi Teknologi Akuakultur, pp. 607-614. http://ejournal-balitbang. kkp.go.id/index.php/fita/article/vie $\mathrm{w} / 3910 / 3362$

Utomo, N.B.P., Susan dan Setiawati, M., 2013. Peran Tepung Ikan dari berbagai bahan baku terhadap pertumbuhan lele sangkuriang Clarias sp. Role of various fishmeal ingredients on sangkuriang catfish Clarias sp. Growth. Jurnal Akuakultur Indonesia, 12(2), pp.158-168. https://doi.org/10.190 27/jai.12.158-168

Watanabe, T., 1988. Fish nutrition and marine culture. JICA Texbook. The General of Aquaculture Course. Departemen of Aquatic. Biosciense. Tokyo. 238 pp.

Yunaidi, Rahmanta, A.P. dan Wibowo, A., 2019. Aplikasi pakan pelet buatan untuk peningkatan produktivitas budidaya ikan air tawar di desa Jerukagung Srumbung Magelang. Jurnal Pemberdayaan: Pulikasi Hasil Pengabdian kepada Masyarakat, 3(1), pp. 45-54. https://doi.org/10. 12928/jp.v3i1.621

Zonneveld, N., Huisman, E.A. dan Boon, J.H., 1991. Prinsip-Prinsip Budidaya Ikan. Gramedia Pustaka Utama. Jakarta. 